\title{
PENGEMBANGAN MEDIA BIMBINGAN DAN KONSELING BERBASIS ISLAMI UNTUK MEMBENTUK KARAKTER MANDIRI ANAK USIA DINI
}

\author{
Oleh: \\ Indah Lestari, S.Pd, M.Pd \\ inles68@yahoo.com \\ Prodi Bimbingan Konseling \\ FKIP Universitas Muria Kudus
}

\begin{abstract}
ABSTRAK
Pelayanan bimbingan dan konseling di lembaga pendidikan anak usia dini dilaksanakan terintegrasi dengan kegiatan pengembangan yang dilakukan oleh pendidik anak usia dini yang ditandai dengan adanya pemahaman yang menyeluruh terhadap karakteristik anak dengan segenap potensinya melalui media permainan.

Inovasi media pelayanan bimbingan dan konseling yang sarat akan nilai sangat diperlukan untuk menyeimbangkan permainan-permainan yang sekarang sudah marak beredar di zaman serba teknologi ini yang kurang memberikan penanaman moral kepada anak usia dini,salah satu aspek yang dapat mendorong percepatan meningkatnya moral anak melalui sentuhan nilai-nilai agama. Hal ini mendasari peneliti untuk mengembangan media bimbingan dan konseling berbasis islami untuk membentuk karakter mandiri anak usia dini kabupeten kudus

Tujuan penelitian adalah untuk mendapatkan media yang tepat dan berhasil guna, jenis penelitian yang digunakan adalah design reseach. Hasil penelitian ini menunjukkan bahwa media yang dikembangkan dapat merangsang dan meningkatkan kemandirian siswa dalam suasana bermain yang menyenangkan.
\end{abstract}

Kata Kunci: Media Bimbingan dan Konseling Islami, Karakter Mandiri

*) Universitas Muria Kudus - Jawa Tengah

\section{PENDAHULUAN}

Berdasarkan data yang diperoleh melalui BPS-Statistics of Kudus Regency menjelaskan nilai IPM kabupatern kudus tahun 2011 sebesar 73,24 dan berada di tingkat 13 jawa tenggah. Nilai ini menunjukkan peningkatan di bandingkan pada tahun 2010 yaitu dengan nilai IPM 72,95. Pada tingkat bakorwil I Provinsi Jawa Tenggah angka IPM kaputen kudus berada di peringkat 2 setelah kabupaten pati. Prestasi yang sudah di dapatkan ini, membuat kabupaten kudus semakin gencar meningkatkan kualitas layanannya, khususnya di bidang pendidikan anak usia dini. Pendidikan usia dini merupakan wahana pendidikan yang sangat fundamental dalam memberikan kerangka dasar terbentuk dan berkembangnya dasar-dasar pengetahuan, sikap dan keterampilan pada anak. Keberhasilan proses pendidikan pada masa dini tersebut menjadi dasar untuk proses pendidikan selanjutnya.

Pada periode emas ini proses pertumbuhan dan perkembangan anak dalam berbagai aspek seperti: fisik, sosioemosional, bahasa dan kognitif sedang mengalami masa yang tercepat dalam rentang perkembangan hidup manusia (Berk,1992 dalam Nurbiana: 2009).

Untuk itu perlu adanya penanaman karakter yang kuat agar anak dapat berkembang dan mampu menjadi pribadi 
yang berkualitas dan mandiri. Peran dari semua pihak sangat diperlukan guna tumbuh kembang anak, khususnya orang tua yang memberikan pelajaran pertama anak di dunia. Bahkan di ungkapkan dalam hadist bahwa setiap anak lahir dalam fitrah. Hal ini diperlukan adanya bimbingan dan asuhan yang maksimal dari orang tua. Demikian pula seorang guru, khususnya konselor sekolah dalam menanamkan karakter siswa, perlu kecapakan yang mumpuni dalam mengaplikasikan karakter melalui dunia anak yaitu bermain.

Berangkat dari permasalahan tersebut, diperlukan suatu media pembelajaran anak usia dini berbasis islami dalam membentuk karakter mandiri mereka. dari berbagai asumsi, peneliti memilih kelompok bermain bintang belia pedawang bae kudus sebagai objek untuk pelaksanaan penelitian. Hal ini di dasarkan dari tujuan penelitian yaitu mengembangkan sebuah media bimbingan dan konseling berbasis islami dalam membentuk karakter mandiri anak usia dini, sehingga dari hasil prototipe media bimbingan dan konseling yang akan dikembangkan nanti dapat di aplikasikan ke tempat pendidikan anak usia dini yang lain.

\section{Metode}

Tujuan akhir dari penelitian ini adalah tersusunnya model media bimbingan dan konseling berbasis islami untuk membentuk karakter mandiri anak usia dini, oleh karena itu penelitian ini menggunakan metode design research, tahapan pelaksanaannya menurut Gravemeijer \& Cobb (2006) adalah: 1) preparing for the experiment (persiapan penelitian), 2) design experiment (pelaksanaan desain eksperimen), dan 3) retrospective analysis (analisis data yang diperoeh dari tahap sebelumnya).penelitian ini dilaksanakan di pendidikan anak usia dini bintang belia kabupatern kudus

Teknik pengumpulan data dalam penelitian ini yaitu 1. Studi dokumen merupakan suatu teknik pengumpulan data dengan menghimpun dan menganalisis dokumendokumen baik dokumen tertulis, gambar, foto maupun elektronik (Syaodih, 2008 : 221). 2. Pengamatan atau observasi Menurut Bodgan \& Tylor, 1975 dalam (Sumaryanto, 2007 :101) dapat diklasifikasikan atas pengamatan melalui cara berperan serta (participant observation). Pada penelitian ini digunakan observasi atau pengamatan berperan serta, karena peneliti ikut melakukan satu fungsi yaitu ikut aktif dalam pelaksanaan kegiatan dilihat dari upaya pembentukan karakter mandiri anak usia dini. 3. Angket digunakan untuk mengumpulkan data respon guru terhadap efek media bimbingan dan konseling berbasis islami dalam membentuk karakter mandiri anak usia dini. 4. Wawancara (interview) adalah percakapan dengan maksud tertentu. Percakapan dapat dilakukan oleh dua pihak yaitu pewawancara (interviewer) yang mengajukan petanyaan dan terwawancara (interviewee) yang memberikan jawaban atas pertanyaan itu (Moleong, 2010 : 187). Wawancara dalam penelitian ini dilakukan pada sumber data utama yaitu: anak, Guru dan para orang tua siswa.

Analisis data dalam penelitian ini dilakukan melalui beberapa langkah yaitu Pengumpulan informasi melalui wawancara, observasi maupun dokumentasi terhadap pelaksanaan media yang sudah diaplikasikan pada anak usia dini, data aktivitas dan pengelolaan proses pembelajaran serta respon guru dianalisis menggunakan data dari hasil sebaran angket. Sedangkan respon siswa di analisis dari hasil wawancara, observasi maupun dokumentasi.

\section{Hasil dan Pembahasan}

Hasil penelitian untuk mendapatkan pengembangan media pembelajaran anak usia dini bintang belia kabupaten kudus, melalui beberapa tahapan yaitu Kajian literatur sekaligus diskusi dengan pakar dan praktisi atau guru yang berpengalaman di bidang pendidikan pada anak usia dini, khususnya dalam membentuk karakter mandiri,

Pada tahap kajian literatur ini, selain peneliti melibatkan pengguna di lapangan atau praktisi anak usia dini yaitu Taufik, S.Pd, M.Pd, peneliti pula melibatkan pakar dalam profesi bimbingan dan konseling bapak Drs. Sucipto, M.Pd, Kons. Hasil yang diperoleh dari kajian literatur yaitu pentingnya membangun sikap kemandirian anak usia dini karena anak yang mandiri akan cenderung berprestasi karena dalam menyelesaikan tugas-tugasnya anak tidak lagi 
tergantung pada orang lain, anak akan tumbuh menjadi pribadi yang percaya diri dan mampu menyelesaikan sesuatu yang menjadi tanggung jawabnya. Dalam hal ini peran orang tua serta pendidik anak usia dini sangat berperan penting bagi terwujudnya kemandirian anak, sehingga jelas sangat diperlukan keahlian serta cara yang efektif dalam mencapai tujuan tersebut. Keefektifan sebuah cara dalam membantu anak menjadi pribadi yang mandiri tentunya perlu diperhatikan karakteristik masing-masing anak tersebut dan mengunakan kegemaran dunia anak yaitu bermain. Dari kegiatan bermain inilah diharapkan dapat di masukkan nilai-nilai kamandirian, sehingga pemilihan jenis permainan yang tepat sangat diperlukan Jenis permainan tersebut dirumuskan dalam permainan boneka jari, lempar bola ke dalam ember, bola bekel, meronce dan puzzle. Pembuatan model media bimbingan dan konseling berbasis islami yang meliputi (a) Rasional, (b) Tujuan, (c) Asumsi, (d) Target Intervensi, (e) Peran Pendidik, (f) Media Permainan, (g) Prosedur Permainan, (h) Aplikasi Indikator Kemandirian dalam Prosedur Permainan, (i) Evaluasi Keberhasilan

Hasil telaah model media awal bimbingan dan konseling dalam membentuk karakter mandiri anak usia dini diharapakan dapat di aplikasikan dengan mudah dan di terima oleh anak-anak dengan suka cita. Untuk itu perlu di susun secara konsep maupun praktis operasional media bimbingan dan konseling berbasis islami dalam membentuk karakter manidri anak usia dini melalui perumusan sebuah model lengkap dengan aturan yang akan digunakan sebagai dasar dalam memainkan permainan tersebut

Media bimbingan dan konseling berbasis islami dengan media mainan bagi pembentukan karakter kemandirian pada anak usia dini dilakukan menjadi beberapa tahapan pada setiap permainan yang ada dalam satu kotak tersebut, pada setiap permainan memiliki prosedur atau tata cara yang berbeda. Sebelum masuk dalam intervensi masing-masing permainan, anak diminta untuk membaca doa belajar dan memahami makna dari doa tersebut terlebih dahulu.
Berikut ini adalah prosedur pada setiap permainan yaitu :

1) Perkenalan Boneka Jari

Pada jenis permainan ini terbagi menjadi beberapa tata cara yang harus dilakukan oleh pendidik yaitu sebagai berikut:

- Ambil boneka jari kemudian pakai dan gunakan untuk bercakap-cakap dengan anak yang sudah disuruh untuk maju kedepan kelas dengan cara bergiliran.

- Ajak anak berbicara dengan boneka tersebut dengan tema-tema tertentu (tema dapat menyesuaikan).

- Buka miniatur panggung yang ada di atas kotak mainan dan kemudian permainan siap dimulai.

2) Tangkap Bola Bernomor

Beberapa tahapan yang dilakukan dalam jenis permainan ini adalah sebagai berikut:

- Bentuk dua kelompok bermain asing-masing kelompok terdiri dari dua anak

- Anak yang satu bertugas sebagai pelempar bola dan yang satunya memegang ember untuk menagkap bola yang dilempar oleh temannya.

- Atur permainan sedemikian rupa agar anak tetap tertib menyelesaikan permaianan sampai bola habis.

- Setelah dua kelompok menyelesaikan permainan, pendidik memberikan instruksi agar masing-masing kelompok mengembilkan bola yang nomornya sama dengan miniatur angka yang diambil atau diinginkan oleh pendidik.

- Berikan instruksi agar anak secara bergantian dalam mengambilkan bola agar tidak terjadi kecemburuan pada anak yang lainnya dalam satu kelompok tersebut.

- Kalau anak berhasil mencocokkan bola dengan angka yang diinginkan oleh pendidik maka berikan satu bintang pada anak sebagai reward.

3) Alur Bola Bekel

Permainan ini meliputi beberapa tahapan yang perlu dilakukan yaitu sebagai berikut:

- Berikan anak beberapa bola bekel dan kemudian mintalah dia untuk menggelindingkan sendiri bola bekel yang dia inginkan.

- Mintalah pada anak-anak agar dia memilih jalan yang paling tepat agar bola bekel dapat masuk kedalam wadah yang tidak berlubang agar anak tidak perlu mengambil bola bekel 
yang jatuh tersebut dan memulai lagi permainannya.

- Ulang terus permainan seperti itu sampai bola bekel habis dan masuk semua kedalam wadah.

4) Lonceng Tiang Meronce

Tahapan-tahapan dalam memainkan permainan ini ada beberapa tahap yang perlu dilakukan yaitu:

- Untuk lonceng sebagai media musik anak bisa memukul sesuka hati sehingga akan timbul bunyi yang dihasilkan dari tabrakan antar lonceng aluminium ketika dipukul anak.

- Setelah anak sudah mulai bosan dengan aktivitas memukul lonceng, lonceng juga bisa dijadikan tiang untuk media meronce anak dengan memasukkan lonceng kedalam lubang yang sudah disediakan.

- Biarkan anak bebas memilih warna maupun bentuk yang ia kehendaki untuk dironce atau guru juga bisa memberikan instruksi kepada anak agar mengambil bidang tertentu sebagai salah satu pembelajaran pengenalan anak terhadap macam-macam bidang.

5) Puzzle

Dalam permianan ini ada beberapa tahapan yang dilakukan, diantaranya yaitu:

Anak dibiarkan bebas mengekspresikan kemampuan mereka dalam menyusun potongan- potongan puzzle sesuka hati mereka. Pendidik hanya sebagai pendamping anak dan tidak diperkenankan untuk mendominasi dalam proses anak menyusun puzzle. Jika diminta oleh anak maka pendidik boleh membantu membimbing anak yang kesulitan.

Setiap permainan memiliki tujuan dalam membentuk karakter mandiri anak usia dini dengan penanaman moral sebagai dasar intervensi dalam media yang dikembangkan. secara lengkap tertuang dalam bahan ajar media bimbingan dan konseling berbasis islami dalam membentuk karakter mandiri anak usia dini.

Adapun skor rata-rata yang diperoleh dari hasil pengamatan penelitian ini yaitu respon siswa mendapatkan hasil 70 dalam kategori sangat baik. Sedangkan respon pendidik anak usia dini terhadap media yang dikembangkan memperolah skor rata-rata 4 dalam kategori baik. Pendidik anak usia dini merasa senang dan mendapatkan wawasan baru bahwa dalam membentuk karakter anak usia dini dalam menyonggsong generasi emas indonesia 2045 perlu mengasah ide dalam membuat sebuah permainan yang inovatif dan normatif agar dapat mewujudkan pembelajaran yang aktif, kreatif, menyenangkan serta berhasil guna.

\section{Simpulan}

Penelitian design research yang telah dilaksanakan telah dapat meghasilkan produk berupa media bimbingan dan konseling berbasis islami dalam membentuk karakter mandiri anak usia dini yang telah di validasi oleh praktisi maupun ahli serta telah di ujicobakan dan efektif. Dengan demikian media ini telah siap digunakan oleh pendidik PAUD dalam melaksanakan pembelajaran dengan mengintegrasikan layanan bimbingan dan konseling berbasis islami untuk meningkatkan kemandirian anak usia dini.

Media yang telah dihasilkan masih perlu di lanjutkan dengan uji keterpakaian produk pada paud yang lain, selain itu masih sangat diperlukan penelitian lanjutan dalam bentuk penelitian dan pengembangan serta penelitian eksperimen. Sehubungan dengan hal di atas, maka sangat diharapkan penelitian pengembangan selanjutnya dapat di fasilitasi oleh pemerintah maupun lembaga universitas muria kudus.

\section{Daftar Pustaka}

Badan Statistis Pusat kabupeten Kudus. 2012. Indeks Pengbangunan Manusia. Tersedia di laman http://www.kuduskab.go.id. Di unduh 09 Desember 2013

Gravemeijer \& Cobb. 2006. "Design Research from a Learning Perspective, dalam Educational Design Research. New York : Routledge. 
Moleong, Lexy. 2010. Metodologi Penelitian Kualitatif. Bandung: PT Remaja Rosdakarya.

Nurbiana, Dhinie. 2009. Konsep dasar anak usia dini. Direktorat tenaga pendidik dan tenaga pendidikan Republik Indonesia.

Sumaryanto F, Totok. 2007. Pendekatan Kuantitatif dan Kualitatif Dalam Penelitian Pendidikan Seni. Semarang: UNNES Press.

Syaodih, Nana. 2008. Metode Penelitian Pendidikan. Bandung: PT. Remaja Rosdakarya 